\title{
Assessment of risk and vulnerability of water induced disaster: A case study of Tinau Watershed, western Nepal
}

\author{
Indra N Manandharł*and Keshav P Poudel‡ \\ † Central Department of Geography, Tribhuvan University, Kirtipur, Kathmandu, NEPAL \\ ‡ Central Department of Education Geography, Tribhuvan University, Kirtipur, Kathmandu, NEPAL \\ * To whom correspondence should be addressed. E-mail: cdg@wlink.com.np, eyeyen@wlink.com.np
}

The Himalayas as a whole is tectonically very active and geomorphologically very unstable. It ishighly vulnerableto water induced disasters likesoil erosion, landslides, floods, glacial lake outburst flood etc due to its high relief, steep slopes, active geology, and intense monsoon rainfall. Moreover, rapid growth of population and consequent changes in land use and land cover, development of infrastructures and man-induced changes in runoff arealso responsible for increased events of landslide and flood hazards. Theloss of lifeand properties from these hazards has been increasing. The livelihood options of the people have been threatening. There is urgent need to develop and implement disaster management activitiesin order to reduce the loss of life and properties and sustain development activities in thisarea. An assessment of hazard, risk and vulnerabilityand its mapping could provide basis for the development of effective disaster management activities. It is in this context, an attempt was made to identify different types of water induced disasters and map and assess its risk and vulnerability. Tinau watershed was selected for this study.Tinau watershed with thetotal area of $234 \mathrm{sq} \mathrm{km}$ lies in Palpa district in western Nepal. The elevation ranges from $330 \mathrm{~m}$ at the confluence of Tinau river and Jhumsa khola (stream) to $1893 \mathrm{~m}$ at Ghustung Lekh.

Both the secondaryand primaryinformation havebeen used. Aerial photographstaken in 1996 wereinterpreted with field verification in order to identify the areas proneto different types of water induced disasters. Local people were consulted and interviewed to gather information for risk and vulnerability assessment. Thefield-work was carried out in September 2003. A total of eleven parameters like lithological units, lineaments, slopegradient, slopeshape, slopeaspects, relativerelief, drainage density, water tableand drainagecondition, land use, vegetation cover, and distance from the road were used for landslide and flood hazard mapping. These information were derived from available analog maps such as toposheets, land system, land utilization, land capability prepared in thepast with modification after field verification. GIS tool was used to analyse above mentioned parametersand preparehazard, risk and vulnerability maps. Hazard areas werecategorized into threegroupsaccording to the probability of occurrenceof hazardssuch as high, moderate and low.

Thelandslidehazard map shows thatabout $17.6 \%$ land liein thehigh hazard zoneand $36.7 \%$ area in themoderatehazard zone In terms of flood hazard zone $11.5 \%$ of the land fallsunder the high and moderately high hazard zoneand $4.7 \%$ of land falls under the moderate hazard zone. As reported by focus group discussion out of 6716 households in the watershed, 2327 households are exposed to hazards of different types. Mostly affected people form river bank cutting, channel shifting and flood in this area are poor landless tenant families. The damage of road due to landslide is common. During the past three years the total value of Highway repair after the damage by landslide was Rs. 714,400.

Attempt was also madeto evaluatedisaster mitigation and management activities carried out in the watershed. The strategies adopted by household to minimizetherisk of landslide, flood and other geomorphic hazards include evacuation from hazard area to other area, construction of small structure to control rive bank cutting and landslide, retaining wall, and tree plantation. The strategies adopted by other GOs and NGOs are mostly post disaster measuresand relief distribution. Thefailure of past relief and post disaster management activities shows the lack of participation of local peoplein theentire processes. There is a lack of local level institutions/ organizations responsible for disaster preparedness. Efforts should be made to create awareness among the local people, involve them in the entire processes of disaster preparedness. The response and recovery capacity of local peopleat present to copewith landslideand flood disasters which are common in the watershed is very low due to mass poverty, illiteracy, low level of off-farm activities and poor service facilities such as health. In this context, it is necessary to improveresponseand recovery capacity of local peoplethrough provision of education, training, off-farm employment opportunitiesand infrastructural services. Emphasisshould also begiven to develop construction standardsfor building and other infrastructures and regular monitoring and maintenance of already constructed infrastructures.

Early warning system hasnot yet been developed. Keeping in view the lead-time of flooding between highland and lowland areas, it isessential to develop a mechanism of community-based warning system. The magnitude of landslide, debris flow, and flood events can be reduced if strong conservation measuresare implemented.

Thisstudy shows that the GISand remotesensingtools can fruitfully be used for landslide and flood hazard and risk assessment. The risks indicated by the combination of vulnerability maps (based on population, economic value of the property, and infrastructure) with hazard maps could be useful in prioritizing areas for the implementation of disaster preparedness plansand mitigation measures. 